\title{
The Consumption of Organic, Traditional, and/or European Eco-Label Products: Elements of Local Production and Sustainability
}

\author{
Eugenia Țigan $^{1}$, Oana Brînzan ${ }^{1}\left[\right.$, Ciprian Obrad $^{2}{ }^{\mathbb{D}}$, Monica Lungu ${ }^{1}$, Nicoleta Mateoc-Sîrb ${ }^{3} \mathbb{D}$, \\ Ioana Anda Milin ${ }^{4, *}$ and Simona Gavrilaș $1, * \mathbb{D}$
}

1 Faculty of Food Engineering, Tourism and Environmental Protection, "Aurel Vlaicu" University of Arad, 2-4 Elena Drăgoi Str., 310330 Arad, Romania; eugenia.tigan@uav.ro (E.T.); oana.brinzan@uav.ro (O.B.); monica.lungu@uav.ro (M.L.)

2 Department of Sociology, West University of Timișoara, 4 Vasile Pârvan Bld., 300223 Timișoara, Romania; ciprian.obrad@e-uvt.ro

3 Department of Management and Rural Development, Banat's University of Agricultural Sciences and Veterinary Medicine “King Michael I of Romania" from Timisoara, Calea Aradului Street no.119, 300645 Timisoara, Romania; nicoletamateocsirb@usab-tm.ro

4 Department of Economics and Company Financing, Banat's University of Agricultural Sciences and Veterinary Medicine "King Michael I of Romania" from Timisoara, Calea Aradului Street no.119, 300645 Timisoara, Romania

check for updates

Citation: T,igan, E.; Brînzan, O.; Obrad, C.; Lungu, M.; Mateoc-Sîrb, N.; Milin, I.A.; Gavrilaș, S. The Consumption of Organic, Traditional, and/or European Eco-Label Products: Elements of Local Production and Sustainability. Sustainability 2021, 13, 9944. https://doi.org/10.3390/ su13179944

Academic Editor:

Francesco Caracciolo

Received: 30 June 2021

Accepted: 31 August 2021

Published: 4 September 2021

Publisher's Note: MDPI stays neutral with regard to jurisdictional claims in published maps and institutional affiliations.

Copyright: (c) 2021 by the authors. Licensee MDPI, Basel, Switzerland. This article is an open access article distributed under the terms and conditions of the Creative Commons Attribution (CC BY) license (https:// creativecommons.org/licenses/by/ $4.0 /)$.
* Correspondence: andamilin@usab-tm.ro (I.A.M.); simona.gavrilas@uav.ro (S.G.); Tel.: +40-740-315-464 or +40-0256-277-440 (I.A.M.); +40-727-762-245 (S.G.)

Abstract: When we talk about products with a low impact on the environment, e.g., organic, traditional, or having the European ecological label, their sales are a central element of the economy. Many variables and local cultural values influence consumer behavior, including education and life requirements. Sustainable development involves education on consumption habits and lowenvironmental-impact production. This article aims to identify the role of education and remuneration in the consumption of sustainable products. Different working hypotheses are formulated. The first hypothesis of our study tests the existence of a direct correlation between the consumer's level of education and their opinion on consuming low-environmental-impact products, influencing the ability to make appropriate decisions. The second one refers to the level of income and consumption behavior. The research method is a statistical one, based on a quantitative analysis and using a questionnaire as a tool. For $60 \%$ of the high-level graduate respondents, a product's source is significant in their choices. Over $70 \%$ of the responders who earn above the median income believe it is essential to consume organic products. The results obtained confirm our initial assumptions. Our findings underline the current knowledge regarding consumption of sustainable products, their characteristics, and consumers' interest in them.

Keywords: sustainable consumption; consumer education; low environmental impact

\section{Introduction}

Consumer education is a two-way relationship that influences the quality of life [1]. Consumer preferences and purchasing options play an important role in supporting sustainable development and environmental protection. Consumption education is also needed to encourage manufacturers to implement low-ecological-impact production systems [2] Consuming and consumer education have multiple implications at the microeconomic and macroeconomic levels, as an educated consumer takes more care of his or her health and manages a budget better. A healthy consumer has high work productivity and quality of life. The consumer education level determines qualitative transformations in the economy by prioritizing environmental protection concerns regarding consumption and 
waste recycling, which lead to sustainable development. Consumer preferences and purchasing options play an important role in supporting durable development and ecosystem protection [2].

Considering consumption as the "final act" of economic interests, it becomes a central concern when discussing organic, traditional food, or European Eco-label products. The target group for these products can be the end goal, but, of course, it can also be the raw material for other finished products. People are considered the final consumers in this research.

The mentioned products have a direct impact on sustainable development. In the economic field, they increase resource efficiency management through waste reduction, reuse, recycling, and ecological design. Energy consumption reduction is encouraged, while the utilization of local, renewable resources decreases the water footprint. Social and cultural ideals stimulate traditional varieties, reintroduce authentic recipes and technologies, encourage social responsibility in consumption, and develop the need for innovation in agri-food products and European Eco-label products and services.

Traditional food products already have a positive image among European consumers [3]. A survey concerning underlined respondents' perceptions of organic food as bringing about positive benefits for humans and the environment, and local products sustains the local economy [4]. Manufacturers in these fields hope to increase consumers' confidence in their products' safety and security [5]. Organic product manufacturing requires compliance with the specific legislation of the selling state. In the European Union, there is an EU regulation that provides guidelines for organic foods. From July 2010, any European product labeled organic guarantees that at least $95 \%$ of its ingredients agree with the specific regulations. The organic farming requirements are different at the European level. According to Eurostat data, only 2.9\% of Romania's total arable land is covered entirely or under conversion areas-less than $20 \%$ of that reported by Spain, the leader in the organic farming domain.

An interesting fact that we should underline regards the varying levels of consumption of organic products in different EU states. In the last decade, the organic market increased by more than $70 \%$ [3]. Comparing the domestic market demand with the production, the most prominent producers, Spain and Italy, experienced overproduction [3], thus encouraging exports and contributing to farmers' income increases. Consumers' concerns about the health and environmental impacts of their actions explain this attitude. A sustainable economy must ensure the best practice models proposed to producers to satisfy consumer demand [4]. The European Commission's latest Communication (25 March 2021) includes a goal of a 25\% increase of land conversion until 2030 and encourages interchanges for organic farming models at the level of EU state members.

Innovative and sustainable food products and processes respond to three primary goals: minimizing the environmental impact, ensuring nutritional and health benefits for consumers, and economic profitability [6]. To anticipate the possible reception of designed goods, one should gather as much information as possible regarding their raw materials, characteristics, production technology, ecological impact, financial details, quality standards, and social indicators [5].

In the EU, the development of sustainable products also includes the labeling sector. Initially, non-foods were given the same eco label. The 2011 ENV.C.1/ETU/2010/0025 report addressed to the European Commission mentioned the ecolabeling interest of $50 \%$ of food manufacturers [6]. This approach is necessary to clarify different legal aspects regarding the term "eco" present on foods and beverage wrappers so as not to mislead the buyer. Awareness of the need for such a method among the population and manufacturers is essential. It supposes familiarity with the impact of all of our activities on the environment.

Different elements are defining contributors of a sustainable global process. Table 1 lists some of them. Producers must take into account new possible raw materials for the food industry. Identifying and exploiting novel resources is an essential step in diversification and simultaneously creates the possibility of the natural, sustainable reestablishment of 
a dedicated eco-friendly industry [7]. All organizations, regardless of the economic sector, have to perform eco-friendly actions through innovative mechanisms, taking into account the present situation and perspectives related to natural sources, principal characteristics, and limited availability [8].

Table 1. Factors of feasible approaches.

\begin{tabular}{ccc}
\hline Sector & $\begin{array}{c}\text { Products: Organic Food Products, Eco-Labeled } \\
\text { Products, and Traditional Food Products }\end{array}$ & Reference(s) \\
\hline \multirow{2}{*}{ Economic } & Varieties adapted to local ecological conditions & {$[10,11]$} \\
Waste reduction & {$[12]$} \\
Reuse, recycling, ecodesign & {$[13]$} \\
Environment & intensive agriculture & {$[14]$} \\
& Energy savings & {$[15,16]$} \\
& Reduced toxicity & {$[17]$} \\
& Use of local, renewable resources & {$[18]$} \\
Reduced water footprint & {$[14,19]$} \\
Waction recycling, e.g., composting & {$[20,21]$} \\
& Traditional cultivars, recipes, and technologies & {$[22]$} \\
& Social responsibility, responsible consumption & {$[23]$} \\
Innovation & {$[24]$} \\
& Safer and healthier food & {$[7]$} \\
\hline
\end{tabular}

It is necessary to begin with the educational system and people's perceptions and correlate these with the designed expectations to ensure the durability of any change. An analysis of the importance of teaching the sustainable approaches fundamentals revealed minimum progress in this area [9].

Many variables that are more or less quantifiable (economic, demographic, and psychological) are used to define consumer behavior characteristics. Local cultural values and traditions also profoundly influence them. When we refer to psychological variables, we are talking about needs or necessities, and might mention Maslow's Hierarchy of Needs, motivations, perceptions, learning, attitudes, and beliefs. The reasons for acquisition can be intrinsic, related to personal determination, or extrinsically associated with the external environment in which everyone carries out their day-to-day activities. Life requirements and changes throughout life alter the buyer's perceptions.

The complexity of the product's purchase also influences a customer. Making correct and efficient acquisition decisions is directly correlated with the product's specific features and the consumer's education and information level [25].

Knowing that education is a two-way relationship, we set out to establish correlations between education, income, and the consumption of sustainable products. For sustainable development to be achieved, education on consumption is necessary. It goes hand in hand with green production technologies. In addition, consumer preferences and purchasing choices play an essential role in supporting sustainable development and environmental protection. The first objective was to assess consumers' knowledge and familiarity level with organic, traditional, and European Eco-label products. The second regarded customers' perceptions of environmentally friendly products', knowing that the product's features influence purchase decisions. In this context, it was necessary to analyze the respondents' thoughts on the products' price and quality in the studied cases, and where they usually buy them.

As the European Eco-label is new on the market, the obstacles to consumers choosing its products were determined. The analyzed products' current situation was outlined and we proposed several possible directions for sustaining economically and ecologically durable approaches, considering all those aspects. 


\section{Literature Review}

Traditional Food Products (TFP) already have a positive image among young European consumers [26]. Organic food is thought to have benefits for consumers and the environment, as well as sustaining the local economy [27]. Producers have high expectations regarding their merchandise, and customers have greater confidence in TFP's safety [28]. Manufacturers know that innovative products and processes and sustainability need to go hand in hand to ensure environmental benefits and consumer safety, fulfill the demand for healthy food, and achieve business profitability [29].

Recently conducted studies distinguished between classes of consumer: the "green segment" with values of self-improvement and openness to change, promoting the welfare of others, buying eco-friendly products, and caring about the environment; "potentially green consumers" who are concerned about the environment and buy organic products but are sensitive to price increases, and the third group, "non-green consumers" driven by achievement and tradition rather than by environmental attitudes [30].

Eco-label perceptions and a lack of awareness, credibility, or motivation are some of the barriers to consumers choosing sustainable food products [31].

The supply and demand market is changing permanently. Producers have to continuously invest in research to offer innovative products that satisfy customers' future necessities. A manufacturer has to project their marketing strategies, taking into account various consumer features. Different mechanisms determine the choice of specific products, such as the emotions created or the differential analysis of the advantages and disadvantages presented. For an informed consumer, the costs involved in an investment will always be of prime importance. On the other hand, an emotional argument will consider other characteristics such as the environmental impact, the raw material origin, or the producer's endeavor to maintain a quality-security equilibrium. Also, the market entry price and customer loyalty are important aspects [32].

The green techniques used in the food industry are not necessarily synonymous with a breaking with tradition. Different studies have underlined the differences between customers' intentions and their actual involvement in organic approaches. A slight change in people's perspective on food waste and manufacturers' use of healthier raw materials and green strategies can protect ecosystems and human life [33]. Simultaneous development of these two attitudes can maintain a product's conventional identity but allow it to be based on sustainable principles [34]

Healthy consumption behavior and an environmentally friendly attitude can contribute to sustainable economic development, social progress, and a better quality of life. Sustainable economic development involves, in addition to economic growth, a series of quantitative, structural, and quantitative transformations that meet current food needs without compromising those of future generations [25]. Adequate information and education programs contribute to the appreciation of organic, traditional, and European Eco-label products.

A sustainable approach refers to an anthropogenic activity performed without depleting available resources, thus ensuring environmental protection and the satisfaction of future generations' needs [35].

The three categories of products considered in this survey directly impact each of the sustainable development pillars. In the economic field, resource efficiency supposes waste reduction, reuse, and recycling. Responsible consumption with the European Eco-label involves, in the environmental sector, saving energy, using local, renewable resources, and reducing one's water footprint; and, in the social and cultural field, using traditional varieties, reintroducing traditional recipes and technologies, prioritizing social responsibility, and developing innovative approaches to both agri-food outcomes and products and services.

Local, regional, and traditional food sectors combine general characteristics, even if they developed under different legislative backgrounds. The consumers appreciate them based on the same criteria. Research results have indicated that customers comprehend 
food standards and tend to buy large quantities [36] and look for premium quality [37]. Ancestral food products contribute to a sense of national cultural values. Studies in Austria and Croatia underlined perceptional similarities regarding consumers' association with well-being and the implications for local farming. Furthermore, food products based on classic recipes remind Croatians of their youth. For Austrians, they represent green products [38].

Producers can successfully apply marketing strategies to upgrade traditional foods. They might take into account a consumer loyalty strategy. Even if consumers do not see such an approach as a defining attribute of classical products, it adds value in their perception [39].

Consumers' motivation to buy eco-labeled products is, in most cases, determined by their intention to make a change towards sustainable practices. The limitation of ecolabeled food products due to the mistake of amalgamating them with organic products does not reflect reality. Survey responders consider such products as imports of a green economy and not necessarily obtained based on organic technology [40]. Buying routines are an important aspect that tips customers' decision-making scales towards a particular product. Strategies to increase the sales of new products also have to be based on the idea that customers' buying habits change. The general idea that eco-labeled products might have a higher price than regular ones negatively affects the purchasing intention, as shown by the responses of a survey [41]. Other factors, however, have a higher significance for acquisition decisions. Usually, consumers evaluate simultaneous product aspects such as usefulness, availability, cost, and nutritional and sensory attributes. Final decisions depend on each individual's reference system. Raising awareness of various aspects related to environmental protection and health may influence classic purchasing tendencies [42].

All actors directly impact the sustainability aspects of production, distribution, and consumption in the food sector. Organic products, eco-labeled products, and traditional food products contribute to the durability of sustainability initiatives.

Organic agriculture is regulated in Romania by Law no. 352/2018. It was modified and completed through the Government Emergency Ordinance no. 34/2000 on organic agrifood products. In Article 1, paragraph 1, the authorities defined organic farming as "the production of agri-food products without the use of chemical synthesis products following the organic production rules." Paragraph 2 contains the following remark: organic "agrifood production aims at achieving sustainable, diversified and balanced farming systems, which ensures the protection of natural resources and consumer health." The specifications comply with the national standards and guidelines. An inspection and certification body set up for this purpose attests to them [43,44].

The International Federation of Organic Agriculture Movements defined four principles. According to those, this type of farming "should encourage and improve soil, plant, animal, and human health, and consider them as integral and indivisible." It should "rely on, work with, imitate and support the living ecological systems and cycles." The "relationships created should ensure equity in terms of the typical environment and life processes." The farmers should guide all specific activities in a "preventive and responsible manner to protect the health and well-being of current and future generations and the environment" [45]. This approach will "lead, unite and assist the organic movement in all its diversity." The vision is of "global adoption of ecological, social and economic systems based on the principles of organic farming" [46].

The European Commission initiative to define 10 indicators for sustainable cities is important from at least two points of view: firstly because they are a set of indicators that reflect the interaction between social, environmental, and economic aspects, which requires local integration; and secondly because, for the first time, it was thought to collect a set of comparable information at the European level, thus making it possible to record the progress made towards sustainable development at a local level. The condition to make these evaluations is the adoption of these indicators by as many local administrations in Europe as possible [47]. On the other hand, we must emphasize that the analysis of 
common European indicators supports the efforts of local authorities in their attempts towards sustainable development. The study of each standardized European indicator reveals the interaction between economic, social, and environmental aspects at the local level, thus allowing for the identification of development trends and directions, and progress made in this regard [48].

Order no. 724/1082/360/2013 defines Traditional Product Certification. According to Article 2(a), a traditional product is a "food product manufactured in national territory and from local raw materials. It does not contain food additives. The way of production and/or the processing uses a traditional recipe. The manufacturers use a traditional technological process that is also distinct from other similar products belonging to the same category" [49].

The European Eco-label is voluntary and designed to encourage economic operators to produce and market low-impact products or services throughout the product or service's life. Both publicly and privately, European consumers consume products or services with a low environmental impact [50]. The European Eco-label is a certification scheme aimed at helping consumers value environmentally friendly products, intending to develop a sustainable society by promoting goods with a minimal impact on the environment and unified health throughout the life cycle of products or services. This voluntary system employs market forces [51]. The concept does not apply to toxic chemicals, pharmaceuticals, or specific medical devices. Instead, all categories of products and services that are not part of those mentioned above, i.e., textiles, footwear, consumer goods, paints and varnishes, computers, tourist services, shops, etc., can have the eco-label [52].

At the European level, the European Eco-label is regulated by EU Regulation 66/2010 [53]. The European Eco-label is held in Romania by GD 661/2011 [54,55].

The survey responses were meant to determine the interviewees' actual performance regarding different aspects of sustainability.

Another reason for the research aim was that the city of Arad is in a plain area, with highly fertile land and an agricultural tradition. For this reason, we investigated the degree of knowledge and use of products with low impact on the environment, knowing that their consumption contributes to sustainable local development.

Starting from these premises, we formulated two hypotheses. The first (H1) claims that customer education influences perceptions about low-environmental-impact products. The second (H2) hypothesis is that income level directly affects consumers' tendency to purchase products with a low impact on the environment, contributing to sustainable development through their lifestyle.

The first hypothesis includes consumers' possible motivations for choosing ecofriendly products. An increased informational standard motivates them to pay attention to health and their surroundings. These are directly associated with the consumption of organic products [56]. Our study also follows on from a proposed investigation [57] regarding the influence of the degree of consumer knowledge on food choices.

The second hypothesis examines the influence of the person's earnings on their willingness to pay more for sustainable merchandise [58].

\section{Materials and Methods}

At the beginning of 2020, 360 responders were interviewed using questionnaires. This number is considered representative for Arad, Romania, which has a population of 177,013.

The expected error taken into account was $\pm 5 \%$, with a probability threshold of $95 \%$ and maximum dispersion. The queries referred to all categories of products examined in the research. The investigation used a quantitative sociological survey as a tool. Subsequently, the data were analyzed and processed through the statistical program IBM SPSS Statistic data editor, Version 20, using varied analysis and correlations.

Each questionnaire included closed, scaled, semi-open, and factual questions. The hypotheses were formulated based on contingency tables and a Chi- squared test was used. 
The survey method used was the statistical step, calculated based on the sample size (360 respondents) and total population (177,013 inhabitants). In such conditions, the statistical step was 492 . For every 492 persons, 1 responded to the questionnaire. If that person did not answer, the next one was asked, and the statistical step was not changed. Each respondent completed the query individually after being told that it was for the purpose of research regarding consuming products that support local sustainability. The respondents were happy to answer questions about income, perhaps because they were only asked for their self-assessment regarding this sensitive matter, not for exact data, which may have caused them to be more restrained with their answers.

Arad and Arad County are located in the Western part of Romania, on the border with Hungary. This is one of the most developed counties in Romania. It has high agricultural potential. Its plains are among the most important production areas for cereals and vegetables. The Agency for Payments and Intervention for Agriculture, Arad [59] stated that, in 2019, there were 21,350 farms in Arad County, which cultivated an area of 353,694.22 ha. Two hundred eighteen agricultural holdings practiced organic agriculture, with a total area of $16,868.51$ ha. The farms that produced organic fruits numbered 18, with a total area of 212.10 ha, while 11 farms cultivated organic vegetables. Still, the organic vegetables were grown with other cereals or fodder. The total cultivated area under organic farming, for all crops, represented only $4.76 \%$ of the entire cropped regions of Arad County. This percentage is constantly growing.

\section{Results}

Two of the products chosen for the present study, organic and traditional products, are included in the 10 Common European Indicators defined by the European Commission during the Third European Conference on Sustainable Cities (Hanover, Germany, 2000), with the 10th indicator being "Products that promote sustainable development" [47].

The respondents on organic products were mostly (36.7\%) aged between 20 and 30 years old. There were nearly equal numbers aged 31 to 50, and 51 to 60, with those over 60 representing only 13.3\%, as presented in Table 2. Most respondents had a high level of education $(43.3 \%)$, followed by those with a high school education (23.3\%) and primary or vocational education graduates (10.0\% each).

Table 2. Sociodemographic characteristics of the respondents to the questionnaires for organic products.

\begin{tabular}{ccc}
\hline Features & Characteristics & Share (\%) \\
\hline \multirow{3}{*}{ Age } & $20-30$ & 36.7 \\
& $31-40$ & 23.3 \\
& $41-50$ & 13.3 \\
& $51-60$ & 13.3 \\
Over 60 & 13.3 \\
\hline \multirow{2}{*}{ Education level } & Primary school & 10.0 \\
& Gymnasium & 6.7 \\
& Vocational school & 10.0 \\
& High school & 23.3 \\
& Post-secondary & 6.7 \\
Income & Higher education & 43.3 \\
\hline & Enough for the bare necessities & 26.7 \\
& Enough for a decent living & 36.7 \\
& Occasionally, we manage to buy some & 6.7
\end{tabular}

It is also worth noting that the vast majority of respondents said they have enough income for a decent living (36.7\%), or have everything they need $(30.0 \%)$; only $26.7 \%$ claimed that their income is enough only for what is strictly necessary. 
The sociodemographic data of the respondents to the questionnaire on European Eco-label products are presented in Table 3. As can be seen, the largest age group was the over- $60 \mathrm{~s}$ at $53.3 \%$, followed by those aged between 31 and $40(23.3 \%)$, and those between 41 and $50(20.0 \%)$. There is a direct correlation between people with higher education and income level. In terms of the level of education, $36.7 \%$ had higher education, while those with a vocational school or primary school education showed equal proportions at $16.7 \%$, and $13.3 \%$ had a high school level of education. The same percentage as those with higher education, $36.7 \%$, considered that they have an income that allows them a decent living. The proportion of those who think they have an income that provides them only with what is strictly necessary was equal to that of those who believe they have everything they constantly need-13.3\% each.

Table 3. Sociodemographic characteristics of the respondents to the questionnaires for European Eco-label products.

\begin{tabular}{|c|c|c|}
\hline Features & Characteristics & Share $(\%)$ \\
\hline \multirow{4}{*}{ Age } & $31-40$ & 23.3 \\
\hline & $41-50$ & 20.0 \\
\hline & $51-60$ & 3.3 \\
\hline & Over 60 & 53.3 \\
\hline \multirow{6}{*}{ Education level } & Primary school & 16.7 \\
\hline & Gymnasium & 10.0 \\
\hline & Vocational school & 16.7 \\
\hline & High school & 13.3 \\
\hline & Post-secondary & 6.7 \\
\hline & Higher education & 36.7 \\
\hline \multirow{4}{*}{ Income } & Enough for the bare necessities & 23.3 \\
\hline & Enough for a decent living & 36.7 \\
\hline & $\begin{array}{l}\text { Occasionally, we manage to buy some } \\
\text { more expensive things }\end{array}$ & 26.7 \\
\hline & We always have everything we need & 13.3 \\
\hline
\end{tabular}

Regarding the characteristics of the sampling used to collect the information through the applied questionnaires, it has to be a strength that the majority of respondents were between 20 and 40 years old (about $60 \%$ of the people questioned). In comparison, $40 \%$ were above 40 . Regarding the gender distribution, the female respondents represented $60 \%$, and males $40 \%$.

\subsection{Knowledge Level}

This research, among other aspects, analyzed consumers' knowledge and familiarity with the three considered notions: organic, traditional, and European Eco-label products. As we see from Figure 1, most consumers know these concepts well: $53.3 \%$ of respondents knew and were interested in organic and traditional products; $33.3 \%$ for organic and $26.7 \%$ for traditional considered that they do not know much, only that they read something about it once. On the other hand, European Eco-label products are much less known, only by $3.3 \%$. Most of the respondents, $43.3 \%$, claimed that they have read and know about these products; $40 \%$ said they do not know a lot about the idea but have heard of it.

From this first evaluation, it can be concluded that there is a significant need for consumer information and continuous training. In addition, it is necessary to provide more opportunities to present what these concepts mean and their impact on human health and the environment. 


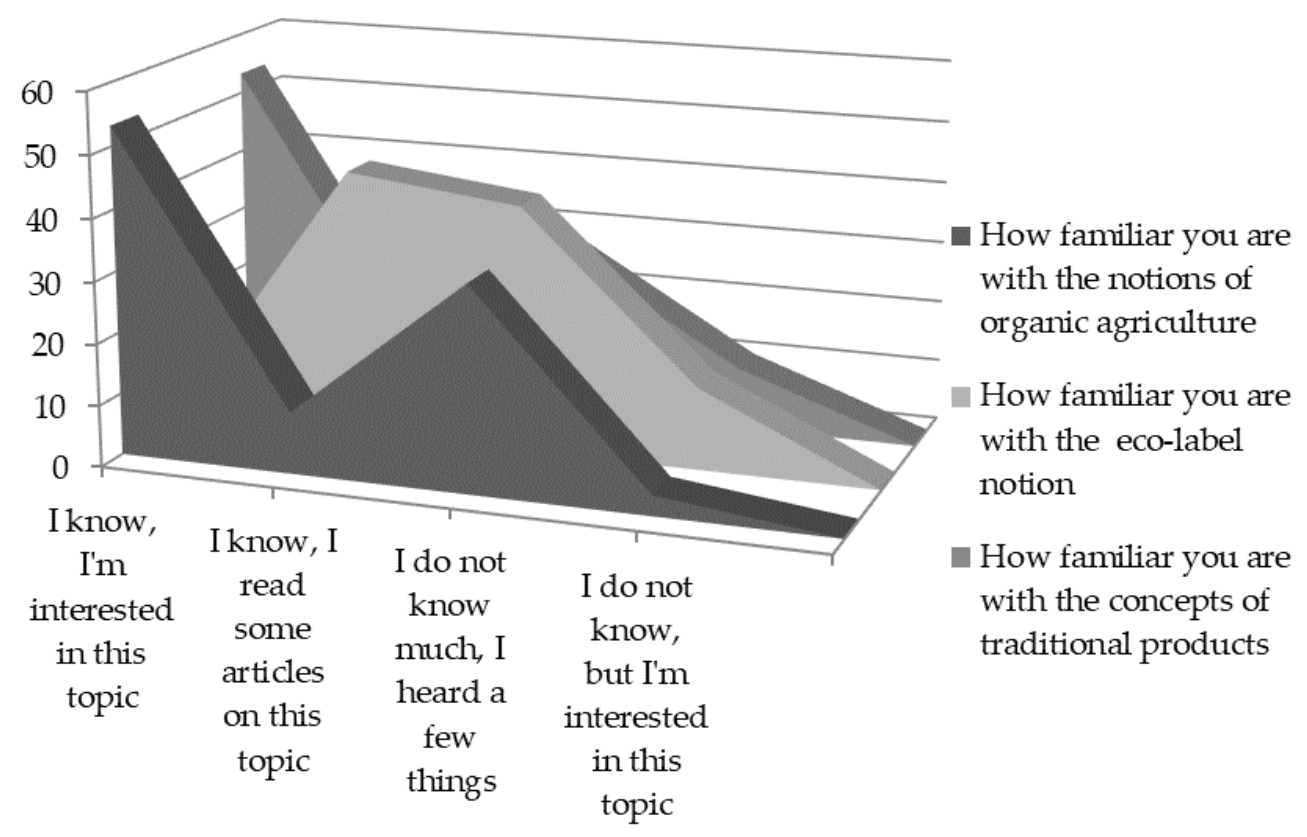

Figure 1. Knowledge level. Source: Data from Field Quizzes, 2020.

A tested hypothesis was that of the growing interest in organic crops according to the respondents' level of education. It was assumed that these products are better known by those with a higher level of education (Table 4).

Table 4. Organic fruit and vegetables' origin—the importance according to the respondents' level of education.

\begin{tabular}{cc}
\hline Training Level & Share (\%) \\
\hline Primary school & 0.0 \\
Gymnasium & 0.0 \\
Vocational school & 23.4 \\
High school & 13.3 \\
Post-secondary & 13.3 \\
Higher education & 50.0 \\
\hline
\end{tabular}

A direct correlation can be seen between the perceived importance of consuming organic vegetables and fruits and the respondents' level of education. While $28.6 \%$ of those with a secondary and vocational education (level 1) consider it essential for vegetables and fruits to come from organic agriculture, the percentage of those with high school and post-secondary education who shared the same opinion is even higher, $37.5 \%$. Moreover, $60 \%$ of the respondents with higher education consider that the provenience is significant.

The hypothesis was verified using contingency tables and the Chi-squared statistical test. According to the analyzed data, we found that $p<0.05$. Consequently, there are differences regarding the perception of organic products' importance based on the education level of the participants in the study. It follows that we reject the null hypothesis and assume the alternative view.

The first hypothesis, referring to the direct correlation between the level of education and consumption of organic products and between consumer income and consumption of organic products, was confirmed (Table 5). The respondents said that it is essential to find an increasing number of products with a low impact on the environment on the market throughout their lives. 
Table 5. Hypothesis check for H1.

\begin{tabular}{cccc}
\hline Value & Df & $\begin{array}{c}\text { Asymptotic } \\
\text { Significance } \\
\text { (2-Sided) }\end{array}$ \\
\hline Pearson Chi-squared & $85,116^{\mathrm{a}}$ & 4 & 0.000 \\
Likelihood ratio & 104,626 & 4 & 0.000 \\
Linear-by-linear association & 65,320 & 1 & 0.000 \\
$N$ of valid cases & 360 & & \\
$\mathrm{a}^{*} 0$ cells $(0.0 \%)$ have expected count less than 5. & &
\end{tabular}

There was more variety in the respondents' statements regarding the income situation: $16.7 \%$ considered that they only have enough resources to cover their strict necessities. In contrast, $36.7 \%$ claimed that they have a decent living and that all their needs are met. These answers reflect the economic situation in Arad, a city with a relatively low unemployment rate, namely 1.2\% in May 2018, according to the Statistical Bulletin of the Statistics Department of Arad County. This rate is 3.5\% less than the national average.

Table 6 gives the statistical significance of this association: $p<0.05$, so the null hypothesis was rejected. It indicates that there is no difference between how the values of the independent variable (income) influence the values of the dependent variable (the perception of the importance of consuming organic food). Indeed, people who constantly manage to have everything they need (an estimated proportion of $72.7 \%$ ) said that it is of important that the products they consume come from organic agriculture. Compared to them, 36-40\% of those who have incomes that only give them the minimum necessary or the minimum for a decent living consistently looked for an organic source of the vegetables and fruits they consumed. So, differences exist and are more and more visible, the higher the incomes in question.

Table 6. Hypothesis check for $\mathrm{H} 2$.

\begin{tabular}{cccc}
\hline & Value & Df & $\begin{array}{c}\text { Asymptotic } \\
\text { Significance } \\
\text { (2-Sided) }\end{array}$ \\
\hline Pearson Chi-Squared & $89.092^{\text {a }}$ & 6 & 0.000 \\
Likelihood ratio & 121.075 & 6 & 0.000 \\
Linear-by-linear Association & 36.454 & 1 & 0.000 \\
$N$ of valid cases & 360 & & \\
$\mathrm{a}^{*} 0$ cells $(0.0 \%)$ have expected count less than 5. &
\end{tabular}

Moving to organic production technology may improve nutritional value, referring to the mineral or total phenolic content [60]. Compared with the conventional approach, a green or organic one ensures the same level of protection with respect to the mycotoxin content [61]. These are suitable premises for the authorities to implement educational and informative programs to increase the land area converted. Their intervention can eliminate or considerably reduce the constraints applied by organic farming regarding the technologies used and the expenses involved [62]. Such initiatives will contribute to economically and environmentally sustainable development.

\subsection{Importance of Using Sustainable Products}

Regarding the importance of using products with a low impact on the environment, most respondents $(46.7 \%)$ said that it is essential for them to use organic products, with traditional or eco-labeled products having proportions of $30 \%$ and over $50 \%$, respectively.

From Figure 2, it can be seen that durable product acquisition is a priority for most of the respondents. Such products develop natural sensory and chemical characteristics. Consumer orientation toward these will promote a healthier nutrition perspective. An initial step represents the development of specific databases containing nutritional information regarding typical products. Based on that approach, healthy recipes can be 
quickly developed [63], and consumers can also have increased confidence in a product's authenticity and safety.

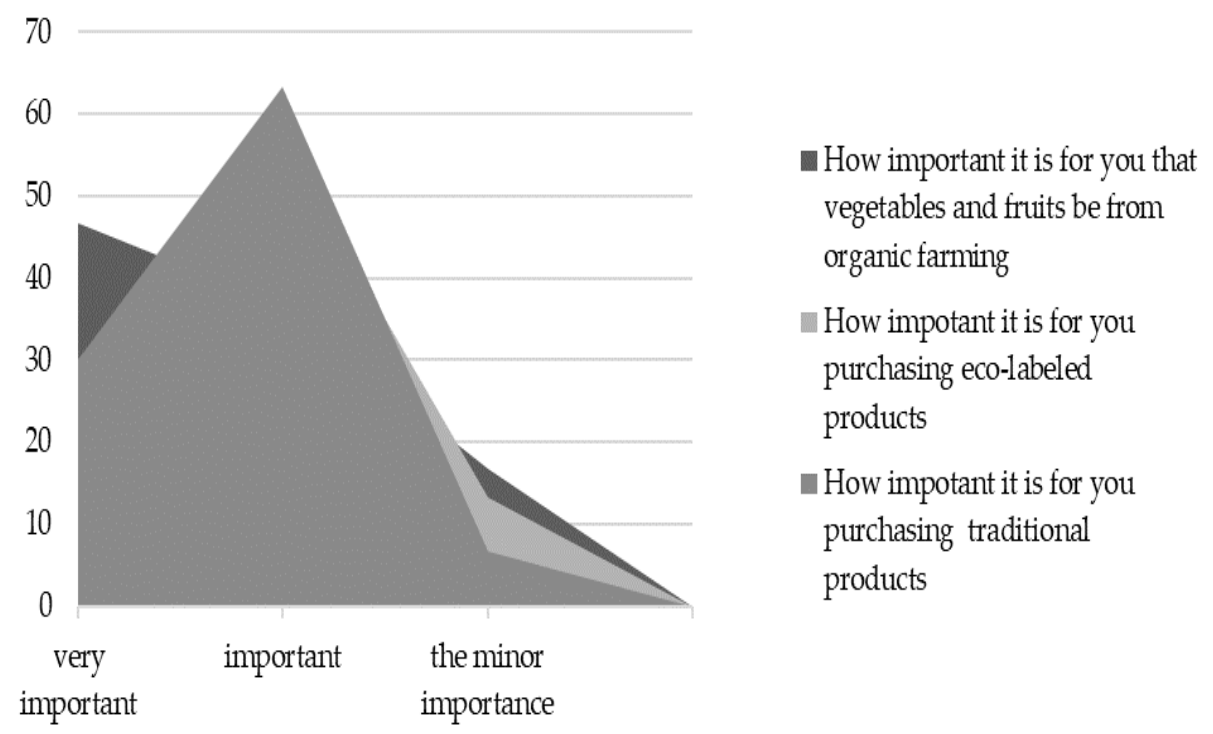

Figure 2. Importance of using sustainable products. Source: Data from Field Quizzes, 2020.

\subsection{Considerations Regarding the Ratio between Quality and Price}

Subsequently, consumers' perceptions regarding the products' quality-price ratio (Figure 3) were analyzed. In approximately equal proportions, most respondents considered organic products to have a reasonable price and superior quality $(73.3 \%)$; for traditional products the proportion was $63.3 \%$, and for products with the European Ecolabel it was $56.7 \%$. However, for these products there were also $25.6 \%$ of respondents who consider that they are products with a high price and low quality. Here we must emphasize that most of the respondents do not know these products well. They only assume that they are produced at a high price and maybe have low quality. We can correlate these assumptions with the level of education and the level of current income.

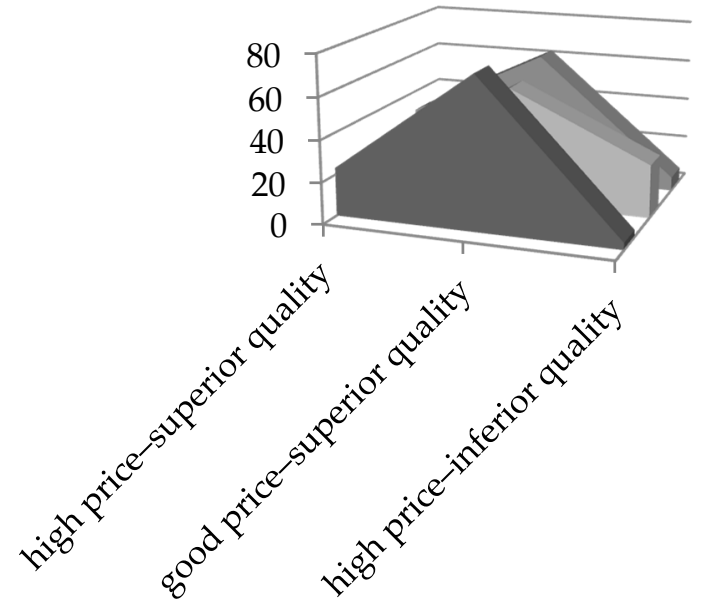
What do you consider the price-quality ratio to be in terms of organic food products?
What do you consider the price-quality ratio to be in terms of eco- label products?
What do you consider the price-quality ratio to be in terms of traditional products?

Figure 3. Quality-price considerations. Source: Data from Field Quizzes, 2020.

\subsection{The Place Where Responders Usually Buy Sustainable Products}

Another aspect analyzed referred to the products' place of acquisition. This question was not asked about European Eco-label products, knowing that they are found only in specific stores for each category of eco-labeled products.

Most respondents (36.7\%) choose specialty stores for organic products, or buy directly from the producers $(23.3 \%)$, highlighting their sense of environmental responsibility 
(Figure 4). The local market supplies $33.3 \%$ of traditional products, followed by supermarkets and rural producers at $23.3 \%$ each.

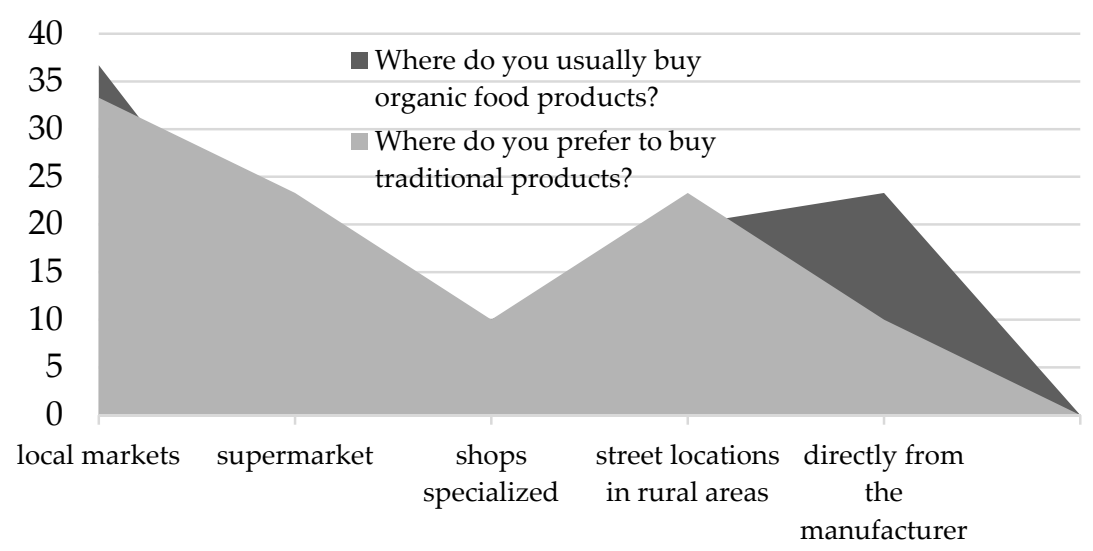

Figure 4. The product suppliers. Source: Data from Field Quizzes, 2020.

Such an approach presents multiple advantages such as direct interaction between customers and the producer, building a relationship of mutual trust, low prices due to the elimination of middlemen, and ensuring high-quality products through a short delivery chain [64].

\subsection{The Reasons Why Eco-Labeled Products Are Not of Interest}

We wanted to know why consumers are not looking to mainly buy products with the European Eco-label. We found that $43.4 \%$ said they are more expensive and so they cannot afford them, $13.3 \%$ said they are more expensive, and $23.3 \%$ said that they simply did not think to buy products with the European Eco-label. What is also noteworthy is the response of the $16.7 \%$ who said they cannot currently find these products (Figure 5). Thus, the European eco-labeled products' distribution level needs to improve alongside the dissemination of better consumer information.

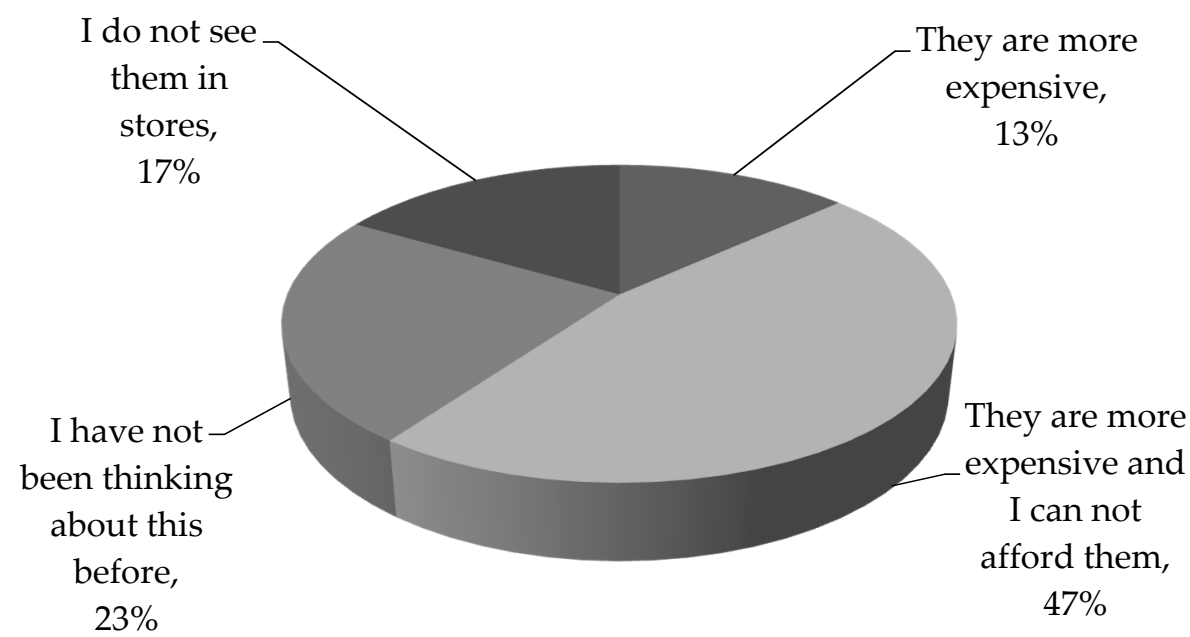

Figure 5. The main reason why you are not looking to purchase eco-labeled products. Source: Data from Field Quizzes, 2020.

Another observation that emerges from the data analysis is that, as the income level of the investigated population increases, it directly impacts the perceived importance of using eco-labeled products. The sign of the Pearson coefficient thus shows a directly proportional link between the two variables: the perceived importance of consumption and the increase in personal income. The magnitude of $r=0.43$ shows the average intensity of the association between these variables (Table 7). 
Table 7. Correlation between the income level and the purchase of products with the European Eco-label.

\begin{tabular}{cccc}
\hline & & Family Income & $\begin{array}{c}\text { The Perceived } \\
\text { Importance of Increasing } \\
\text { the Number and Range of } \\
\text { Eco-Label Products }\end{array}$ \\
Family income & Pearson correlation & 1 & $433^{* *}$ \\
& Sig. (2-tailed) & $N$ & 360 \\
The perceived importance of & Pearson correlation & $433^{* *}$ & 360 \\
increasing the number and & Sig. (2-tailed) & 0.000 & 1 \\
range of eco-label products & $N$ & 360 & 360 \\
\hline
\end{tabular}

** Correlation is significant at the 0.01 level (2-tailed).

The highest degree achieved was another variable that we considered as being important to the present study. About $30 \%$ of the respondents had a primary school education (primary, secondary, and vocational school), about $30 \%$ had graduated high school, and about $40 \%$ had higher education.

Regarding family income, the subjects can be divided into categories by the following statements: "our income is not enough for our needs" $(26.7 \%)$, "our income is enough for a decent living" (43.3\%), and "we always have everything we need" (30\%).

Beyond the difficulties and limitations encountered due to the COVID-19 pandemic, the research highlighted more essential aspects than the study's hypotheses considered. The two theories underline that products with the European Eco-label would most likely be consumed more if local or national distribution improved. Another important aspect, as indirectly expressed by consumers, is the possibility of purchasing products with a short distribution chain or local products. Consumers prefer to buy directly from producers or from specialty stores, choosing products with a low impact on the environment, so their gesture determines an even greater sense of responsibility for sustainable development, which should be appreciated.

These highlighted aspects will be the starting points for future research.

\section{Discussion}

We confirmed the two hypotheses of the research. H1 claimed that the level of education of consumers influences their perception of the importance of consuming products with a low impact on the environment.

Thus, there is a direct correlation between organic produce's perceived importance and respondents' level of education. While $28.6 \%$ of those with secondary and vocational education (level 1) considered it essential that vegetables and fruits come from organic farming, the percentage of those with high school and post-high school education who shared the same opinion was even higher, at 37.5\%. Moreover, $60 \%$ of high-level graduate respondents considered the source to be significant. All of this shows the importance of continued education throughout one's life. Promoting short- or long-term courses on low-environmental-impact products' sustainability and consumption can help scientists submit proposals for further research on innovative products and technologies. At the same time, farmers can direct their attention to consumers' required products.

The second hypothesis (H2) was that consumers' income level directly influences their consumption of products with a low environmental impact, with these people contributing to sustainable development through their lifestyle.

Among the respondents who constantly manage to have everything they need, 72.7\% considered it essential that the products they consume come from organic farming. Compared to them, 36-40\% of those who had a decent living appreciated the importance of organic vegetables and fruit. Such an attitude is conditioned by the media misrepresenting organic products as overpriced [65]. Sánchez-Bravo et al. reported the same results regard- 
ing consumers' intention to pay a higher price for eco-friendly products [66]. Therefore, the second hypothesis was confirmed by the research.

The current research has also highlighted the general level of knowledge about types of products with a low environmental impact. In this sense, research has shown that organic and traditional products are well known. The situation is the opposite for European Eco-label ones.

In addition, we hoped to determine why consumers mainly do not want to buy European Eco-label products. We found that $43.4 \%$ say they are more expensive and so they cannot afford them, but-remarkably-23.3\% said that it simply did not occur to them to buy products with the European eco-label on the market in Arad. What is also significant is the response of the $16.7 \%$ who said they cannot find these products at present. Thus, we can see two elements that could improve the use of European Eco-label products: better consumer information, and more widespread local and national distribution. Also, in this case, the products' credibility would increase the label's validity [67].

Another observation that emerged from the data analysis was that, as the income level of the investigated population increases, so does the importance given to eco-labeled products.

These aspects open up a perspective for new research on European Eco-label products to assess the presence of these products on the Romanian market, especially in Arad. What is the level of information on these products and what is the consumer accessibility degree to these products? These are just some of the directions for future research.

These are some reasons why we consider that unique consumer associations can facilitate the promotion of organic, traditional, and European eco-label products. At the same time, specific educational programs can inform potential consumers about the quality and benefits of these products in terms of personal health and environmental protection.

In this sense, we are in favor of disseminating the results of the innovative project Erasmus+ ORGAFARM, which aims to educate manufacturers of organic products through online platforms. All information regarding organic agriculture, including documentation, specific legislation, crop technologies, processing, and their final capitalization at the European level and in Turkey, the partner country in the project, are presented.

Creating a framework for consumer information and awareness will emphasize the difference between intentional learning and the formal or institutionalized education of the consumer, whose ultimate goal is to obtain a diploma, not necessarily to accumulate new knowledge. Deliberate and conscious learning is what adds value to the consumer.

\section{Conclusions}

The research began from the premise of analyzing the degree of knowledge and use of products that support the sustainable development of Arad, focusing on three types of products: organic, eco-labeled products, and traditional.

As a result of the study, it is evident that approximately $50 \%$ of the respondents had a higher or medium level of education. They know about organic and traditional products and frequently use them. A good number of them know the eco-label or are interested in learning about it. This category of respondents has a constant income. They have the liberty of buying certain products even if they have a higher price and are interested in issues related to sustainability.

A particular behavior was noted for respondents regarding the European Eco-label products. This notion was less well known, with its products more challenging to find in the Arad market and presenting slightly higher prices, as determined from the interviewees' answers. As noted in the research, there is a direct correlation between rising consumer income and interest in products with the European Eco-label. There is also a direct correlation between the level of supply and consumption of organic products, and between consumer income and the consumption of organic products. As the level of education and income level increase, there is increasing interest in consuming products that positively influence local, sustainable development. 
All of the results from the research are relevant, as more than $50 \%$ of consumers are familiar with organic, eco-labeled, and traditional products and interested in using them, which gives us an idea of the drive towards sustainable development in the area under study. We recommend making Arad city market better known for products that promote sustainable development by all possible means, starting with campaigns in schools and universities and including fairs and exhibitions, traditional and social media, and the Internet.

Another approach regarding education on consuming products with a low impact on the environment involves producers and not just trainees. They could better highlight the positive effects of their products on human health and the environment by organizing meetings with consumers on their farms or at fairs. As mentioned, the investigation began shortly before the pandemic started. For us, it was challenging to evaluate the current situation and how it will turn out. The lockdown period that followed restricted our research. For this reason, there were only a limited number of responses analyzed. Also, in this situation, there is the question of statistical representativeness. To ensure the relevance of the method used in this study - a direct approach that did not include supplementary variables-we decided not to continue the research online. This is a limitation of the present study.

Apart from the fact that the research was challenging to complete due to the pandemic, another limitation was that respondents did not know about European Eco-label products for the most part. The results have made us even more determined to make these products known through all the means at our disposal, especially by creating educational programs.

Author Contributions: Conceptualization, E.T. and M.L.; data curation, E.T.; formal analysis, O.B.; investigation, E.T.; methodology, E.T., C.O., N.M.-S. and I.A.M.; supervision, O.B.; writing-original draft, E.T., C.O. and S.G. All authors have read and agreed to the published version of the manuscript.

Funding: This research received no external funding.

Institutional Review Board Statement: Not applicable.

Informed Consent Statement: Informed consent was obtained from all subjects involved in the study.

Conflicts of Interest: The authors declare no conflict of interest.

\section{References}

1. Negrea, M.T.; Voinea, L. Studiul si Protectia Consumatorului; ASE Publishing House: Bucharest, Romania, 2013; ISBN 9786065057340.

2. Dinu, V.; Savoiu, G.G.; Tachiciu, L. Eco-Labeling and Consumers' Education framework. In Proceedings of the 18th IGWT Symposium, Technology and Innovation for a Sustainable Future: A Commodity Science Perspective, Roma, Italy, 24-28 September 2012.

3. Commission, E. Organic Farming in the EU. Available online: https://ec.europa.eu/info/sites/info/files/food-farming-fisheries/ farming/documents/market-brief-organic-farming-in-the-eu_mar2019_en.pdf (accessed on 9 April 2021).

4. Lukman, R.K.; Glavic, P.; Carpenter, A.; Virtic, P. Sustainable consumption and production-Research, experience, and development-The Europe we want. J. Clean. Prod. 2016, 138, 139-147. [CrossRef]

5. Damjan Krajnc, P.G. Indicators of sustainable production. Clean Technol. Environ. Policy 2003, 5, 279-288. [CrossRef]

6. Helmut Sengstschmid, N.S.; Otto Schmid, N.S.; Hanna Stolz, A.S. EU Ecolabel for Food and Feed Products-Feasibility Study (ENV.C.1/ETU/2010/0025). Available online: https://ec.europa.eu/environment/ecolabel/documents/Ecolabel_for_food_ final_report.pdf (accessed on 10 April 2021).

7. Ferraris, F.; Iacoponi, F.; Raggi, A.; Baldi, F.; Fretigny, M.; Mantovani, A.; Cubadda, F.J.F.; Toxicology, C. Essential and toxic elements in sustainable and underutilized seafood species and derived semi-industrial ready-to-eat products. Food Chem. Toxicol. 2021, 154, 112331. [CrossRef]

8. Calabrese, A.; Costa, R.; Ghiron, N.L.; Tiburzi, L.; Pedersen, E.R.G.J.T.F.; Change, S. How sustainable-orientated service innovation strategies are contributing to the sustainable development goals. Technol. Forecast. Soc. Chang. 2021, 169, 120816. [CrossRef]

9. Correa, M.; Lima, B.V.D.; Martins, V.W.B.; Rampasso, I.S.; Anholon, R.; Quelhas, O.L.G.; Leal, W. An analysis of the insertion of sustainability elements in undergraduate design courses offered by Brazilian higher education institutions: An exploratory study. J. Clean. Prod. 2020, 272, 122733. [CrossRef]

10. Wan, N.F.; Su, H.H.; Cavalieri, A.; Brack, B.; Wang, J.Y.; Weiner, J.; Fan, N.N.; Ji, X.Y.; Jiang, J.X. Multispecies co-culture promotes ecological intensification of vegetable production. J. Clean. Prod. 2020, 257, 120851. [CrossRef] 
11. Klaus, V.H.; Kiehl, K. A conceptual framework for urban ecological restoration and rehabilitation. Basic Appl. Ecol. 2021, 52, 82-94. [CrossRef]

12. Yadav, D.; Kumari, R.; Kumar, N.; Sarkar, B. Reduction of waste and carbon emission through the selection of items with cross-price elasticity of demand to form a sustainable supply chain with preservation technology. J. Clean. Prod. 2021, $297,126298$. [CrossRef]

13. Chia, W.Y.; Chew, K.W.; Le, C.F.; Lam, S.S.; Chee, C.S.C.; Ooi, M.S.L.; Show, P.L. Sustainable utilization of biowaste compost for renewable energy and soil amendments. Environ. Pollut. 2020, 267, 115662. [CrossRef] [PubMed]

14. Rahman, M.M.; Aravindakshan, S.; Hoque, M.A.; Rahman, M.A.; Gulandaz, M.A.; Rahman, J.; Islam, M.T.J.E.; Indicators, S. Conservation tillage (CT) for climate-smart sustainable intensification: Assessing the impact of CT on soil organic carbon accumulation, greenhouse gas emission and water footprint of wheat cultivation in Bangladesh. Environ. Sustain. Indic. 2021, 10, 100106. [CrossRef]

15. Xu, Y.; Szmerekovsky, J. System dynamic modeling of energy savings in the US food industry. J. Clean. Prod. 2017, 165, 13-26. [CrossRef]

16. da Rosa, F.S.; Lunkes, R.J.; Spigarelli, F.; Compagnucci, L. Environmental innovation and the food, energy and water nexus in the food service industry. Resour. Conserv. Recycl. 2021, 166, 105350. [CrossRef]

17. Dastan, S.; Ghareyazie, B.; Pishgar, S.H. Environmental impacts of transgenic Bt rice and non-Bt rice cultivars in northern Iran. Biocatal. Agric. Biotechnol. 2019, 20, 101160. [CrossRef]

18. Das, S.; Ray, A.; De, S. Optimum combination of renewable resources to meet local power demand in distributed generation: A case study for a remote place of India. Energy 2020, 209, 118473. [CrossRef]

19. Palhares, J.C.P.; Morelli, M.; Novelli, T.I. Water footprint of a tropical beef cattle production system: The impact of individualanimal and feed management. Adv. Water Resour. 2021, 149, 103853. [CrossRef]

20. Sharma, P.; Gaur, V.K.; Sirohi, R.; Varjani, S.; Kim, S.H.; Wong, J.W.C. Sustainable processing of food waste for production of bio-based products for circular bioeconomy. Bioresour. Technol. 2021, 325, 124684. [CrossRef] [PubMed]

21. Lopes, I.G.; Braos, L.B.; Cruz, M.C.P.; Vidotti, R.M. Valorization of animal waste from aquaculture through composting: Nutrient recovery and nitrogen mineralization. Aquaculture 2021, 531, 735859. [CrossRef]

22. Bernardi, B.; Falcone, G.; Stillitano, T.; Benalia, S.; Bacenetti, J.; De Luca, A.I. Harvesting system sustainability in Mediterranean olive cultivation: Other principal cultivar. Sci. Total Environ. 2021, 766, 142508. [CrossRef] [PubMed]

23. Yusoff, Y.M.; Omar, M.K.; Zaman, M.D.K.; Samad, S.J.J.o.C.P. Do all elements of green intellectual capital contribute toward business sustainability? Evidence from the Malaysian context using the Partial Least Squares method. J. Clean. Prod. 2019, 234, 626-637. [CrossRef]

24. Alqalami, T.A.J.H. Dynamic transparency in design: The revival of environmental sustainability in design elements of Iraqi buildings. Heliyon 2020, 6, e05565. [CrossRef] [PubMed]

25. Cristina Burghelea, M.I.A. Educaţia-Factor determinant al situaţiei consumatorului în era schimbărilor tehnologice. Amfiteatru Econ. 2014, XVI, 451-466.

26. Vlontzos, G.; Kyrgiakos, L.; Duquenne, M.N. What Are the Main Drivers of Young Consumers Purchasing Traditional Food Products? European Field Research. Foods 2018, 7, 22. [CrossRef] [PubMed]

27. Scholl-Grissemann, U. Do consumers care about the message a claim conveys? The magic bullet effect of organic and domestic claims on food products. J. Consum. Behav. 2018, 17, e21-e28. [CrossRef]

28. Mesić, Ž.; Božić, M.; Cerjak, M. The impact of geographical indications on the competitiveness of traditional agri-food products. J. Cent. Eur. Agric. 2017, 18,1-14. [CrossRef]

29. Arcese, G.; Flammini, S.; Lucchetti, M.C.; Martucci, O. Evidence and Experience of Open Sustainability Innovation Practices in the Food Sector. Sustainability 2015, 7, 8067-8090. [CrossRef]

30. Verain, M.C.D.; Bartels, J.; Dagevos, H.; Sijtsema, S.J.; Onwezen, M.C.; Antonides, G. Segments of sustainable food consumers: A literature review. Int. J. Consum. Stud. 2012, 36, 123-132. [CrossRef]

31. Grunert, K.G. Sustainability in the food sector: A consumer behaviour perspective. Int. J. Food Syst. Dyn. $2011,2,207-218$.

32. Genc, T.S.; De Giovanni, P.J.C.; Consumption, R. Dynamic pricing and green investments under conscious, emotional, and rational consumers. Clean. Responsible Consum. 2021, 2, 100007. [CrossRef]

33. Chen, C.-C.; Sujanto, R.Y.; Tseng, M.-L.; Fujii, M.; Lim, M.K. Sustainable consumption transition model: Social concerns and waste minimization under willingness-to-pay in Indonesian food industry. Resour. Conserv. Recycl. 2021, 170, 105590. [CrossRef]

34. Guine, R.P.F.; Florenca, S.G.; Barroca, M.J.; Anjos, O. The duality of innovation and food development versus purely traditional foods. Trends Food Sci. Technol. 2021, 109, 16-24. [CrossRef]

35. Romanian Academy, Dictionarul Explicativ al Limbii Romane/The Explanatory Dictionary of the Romanian Language, Univers Enciclopedic Publishing House; Univers Enciclopedic Publishing House: Bucharest, Romania, 2005; ISBN 978-606-704-161-3.

36. Fernandez-Ferrin, P.; Calvo-Turrientes, A.; Bande, B.; Artaraz-Minon, M.; Galan-Ladero, M.M. The valuation and purchase of food products that combine local, regional and traditional features: The influence of consumer ethnocentrism. Food Qual. Prefer. 2018, 64, 138-147. [CrossRef]

37. Balogh, P.; Bekesi, D.; Gorton, M.; Popp, J.; Lengyel, P. Consumer willingness to pay for traditional food products. Food Policy 2016, 61, 176-184. [CrossRef] 
38. Renko, S.; Cerjak, M.; Haas, R.; Brunner, F.; Tomić, M.J.B.F.J. What motivates consumers to buy traditional food products? Evidence from Croatia and Austria using word association and laddering interviews. Br. Food J. 2014, 116, 1726-1747. [CrossRef]

39. Chrysochou, P.; Krystallis, A.; Giraud, G. Quality assurance labels as drivers of customer loyalty in the case of traditional food products. Food Qual. Prefer. 2012, 25, 156-162. [CrossRef]

40. Bougherara, D.; Combris, P. Eco-labelled food products: What are consumers paying for? Eur. Rev. Agric. Econ. 2009, 36, 321-341. [CrossRef]

41. Grankvist, G.; Biel, A. The importance of beliefs and purchase criteria in the choice of eco-labeled food products. J. Environ. Psychol. 2001, 21, 405-410. [CrossRef]

42. Grankvist, G.; Biel, A. Predictors of purchase of eco-labelled food products: A panel study. Food Qual. Prefer. 2007, 18, 701-708. [CrossRef]

43. Romania, T.P.O. Law Amending and Supplementing Government Emergency Ordinance no. 34/2000 on Biologic Food Products. 2000. Available online: https:/ / www.madr.ro/docs/agricultura/agricultura-ecologica/2019/ordonanta-urgenta-nr-34-2000update-15.10.2019.pdf (accessed on 9 April 2021).

44. Parliament, T.R. LAW no. 352 of 27 December 2018 for the Amendment and Completion of the Government Emergency Ordinance no. 34/2000 Regarding Ecological Agri-Food Products. 2018. Available online: http:/ /legislatie.just.ro/Public/DetaliiDocument/ 21942 (accessed on 9 April 2021).

45. The European Green Pact. Available online: https://ec.europa.eu/info/food-farming-fisheries/farming/organic-farming/ organic-action-plan_ro (accessed on 9 April 2021).

46. Ifoam Organics International. Available online: https://www.ifoam.bio/ (accessed on 9 April 2021).

47. Union, E. Cities of Tomorrow Challenges, Visions, Ways Forward. Available online: https://ec.europa.eu/regional_policy/ sources/docgener/studies/pdf/citiesoftomorrow/citiesoftomorrow_final.pdf (accessed on 18 June 2021).

48. ISPRA. ECI-European Common Indicators (Indicatori Comuni Europei). Available online: http://www.sinanet.isprambiente. it/gelso/rassegna-degli-strumenti-di-sostenibilita-per-gli-enti-locali/indicatori-comuni-europei-eci-european-commonindicators (accessed on 20 June 2021).

49. Rurale, M.A.ș.D. Ordin nr. 360 din 31 Octombrie 2013 Privind Atestarea Produselor Tradiţionale. 2013. Available online: http:/ / legislatie.just.ro/Public/DetaliiDocumentAfis/152470 (accessed on 18 June 2021).

50. Ministerul Mediului, A.ș.P. Eticheta Ecologică Europeană. Available online: http://www.mmediu.ro/categorie/etichetaecologica-europeana/30 (accessed on 18 June 2021).

51. Commission, E. EMAS and Ecolabel Fitness Check. Available online: https://ec.europa.eu/environment/emas/emas_ publications/policy / fitness_check_en.htm (accessed on 18 June 2021).

52. Commission, T.E. Ecolabel. Available online: https:/ / ec.europa.eu/environment/ecolabel/ (accessed on 10 June 2021).

53. Union, E. Regulation (EC) No 66/2010 of the European Parliament and of the Council of 25 November 2009 on the EU Ecolabel. Available online: https:/ / eur-lex.europa.eu/LexUriServ/LexUriServ.do?uri=OJ:L:2010:027:0001:0019:en:PDF (accessed on 18 June 2021).

54. European Parliament, Council of the E.U. Regulation (EC) No 1980/2000 of the European Parliament and of the Council of 17 July 2000 on a Revised COMMUNITY Eco-Label Award Scheme. Available online: https:/ / eur-lex.europa.eu/legal-content/EN/ ALL/?uri=celex\%3A32000R1980 (accessed on 18 June 2021).

55. Guvernul. HOTĂRÂRE nr. 661 din 29 Iunie 2011 Privind Stabilirea unor Măsuri Pentru Asigurarea Aplicării la Nivel Naţional a Prevederilor Regulamentului (CE) nr. 66/2010 al Parlamentului European şi al Consiliului din 25 Noiembrie 2009 Privind Eticheta UE Ecologică. 2011. Available online: http://legislatie.just.ro/Public/DetaliiDocumentAfis/129845 (accessed on 18 June 2021).

56. Sreen, N.; Dhir, A.; Talwar, S.; Tan, T.M.; Alharbi, F. Behavioral reasoning perspectives to brand love toward natural products: Moderating role of environmental concern and household size. J. Retail. Consum. Serv. 2021, 61, 102549. [CrossRef]

57. Menger-Ogle, A.D.; Graham, D.J. The influence of front-of-package nutrition claims on food perceptions and purchase intentions among Nepali consumers. Food Qual. Prefer. 2018, 66, 160-170. [CrossRef]

58. Laroche, M.; Bergeron, J.; Barbaro-Forleo, G.J.J. Targeting consumers who are willing to pay more for environmentally friendly products. J. Consum. Mark. 2001, 18, 503-520. [CrossRef]

59. Centrul Judetean APIA Arad, Serviciu Autorizare Plăţi-IT. Available online: http://www.apia.org.ro/ro/centre-judetene-apia/ arad (accessed on 9 April 2021).

60. Wang, J.; Chatzidimitriou, E.; Wood, L.; Hasanalieva, G.; Markellou, E.; Iversen, P.O.; Seal, C.; Baranski, M.; Vigar, V.; Ernst, L.; et al. Effect of wheat species (Triticum aestivum vs. T. spelta), farming system (organic vs. conventional) and flour type (wholegrain vs. white) on composition of wheat flour-Results of a retail survey in the UK and Germany-2. Antioxidant activity, and phenolic and mineral content. Food Chem.-X 2020, 6, 100091. [CrossRef] [PubMed]

61. Wang, J.; Hasanalieva, G.; Wood, L.; Markellou, E.; Iversen, P.O.; Bernhoft, A.; Seal, C.; Baranski, M.; Vigar, V.; Ernst, L.; et al. Effect of wheat species (Triticum aestivum vs. T. spelta), farming system (organic vs. conventional) and flour type (wholegrain vs. white) on composition of wheat flour; results of a retail survey in the UK and Germany-1. Mycotoxin content. Food Chem. 2020, 327, 127011. [CrossRef] [PubMed]

62. Case, S.D.C.; Oelofse, M.; Hou, Y.; Oenema, O.; Jensen, L.S. Farmer perceptions and use of organic waste products as fertilisers -A survey study of potential benefits and barriers. Agric. Syst. 2017, 151, 84-95. [CrossRef] 
63. Lucarini, M.; Saccani, G.; D’Evoli, L.; Tufi, S.; Aguzzi, A.; Gabrielli, P.; Marletta, L.; Lombardi-Boccia, G.J.F.c. Micronutrients in Italian ham: A survey of traditional products. Food Chem. 2013, 140, 837-842. [CrossRef] [PubMed]

64. Robina-Ramirez, R.; Chamorro-Mera, A.; Moreno-Luna, L. Organic and online attributes for buying and selling agricultural products in the e-marketplace in Spain. Electron. Commer. Res. Appl. 2020, 42, 100992. [CrossRef]

65. Taghikhah, F.; Voinov, A.; Shukla, N.; Filatova, T.J.J.o.R.; Services, C. Shifts in consumer behavior towards organic products: Theory-driven data analytics. J. Retail. Consum. Serv. 2021, 61, 102516. [CrossRef]

66. Sanchez-Bravo, P.; Chambers, E.; Noguera-Artiaga, L.; Sendra, E.; Chambers, E.; Carbonell-Barrachina, A.A. Consumer understanding of sustainability concept in agricultural products. Food Qual. Prefer. 2021, 89, 104136. [CrossRef]

67. Gorton, M.; Tocco, B.; Yeh, C.-H.; Hartmann, M.J.E.E. What determines consumers' use of eco-labels? Taking a close look at label trust. Ecol. Econ. 2021, 189, 107173. [CrossRef] 